\title{
Effect of organic manures on nutritional quality of chicory under water deficit
}

\author{
A. Rahimian Boogar, F. Saedi and S. M. Mosavi Nik* \\ Department of Horticulture Science, College of Agriculture, Zabol University, Zabol, Iran.
}

Accepted 3 September, 2018

\begin{abstract}
Drought stress and organic manure have vigorous role in plant growth. In order to alleviate effects of drought on chicory (Chicorium intybus L.), poultry and livestock manures were used at different levels of drought which induced according to evaporate level from evaporation pan. Aim of this research was to improve the chicory nutritional and pharmaceutical suitability under drought. Results suggested significant effects of both manures on chicory mineral accumulation and phytochemicals. The highest concentration of potassium $(\mathrm{K})$, phosphorus $(\mathrm{P})$ and manganese $(\mathrm{Mn})$ were obtained with poultry application at moderate drought, but no significant difference with livestock manure on potassium in severe drought. Livestock manure usage increased zinc (Zn) concentration in severe drought significantly. Both manures increased total phenolic compounds in severe drought significantly, but total carbohydrate significantly affected by poultry manure. Therefore, chicory inulin and chicoric acid under drought conditions were significantly affected by both poultry and livestock manures.
\end{abstract}

Keywords: Livestock manure, poultry manure, mineral accumulation, phytochemical, drought stress, Chicorium intybus.

*Corresponding author. E-mail: mohsen_372001@yahoo.com.au. Tel: (+98) 9155613032.

\section{INTRODUCTION}

Common chicory (Cichorium intybus L.) is a typical Mediterranean vegetative herb with variegation of utilization (Castellini et al., 2007; Mulabagal et al., 2009; Sinkovič et al., 2015). Chicory is an edible herb with prevalent applications in many areas of Iran includes raw vegetable and salad, cooking edible, medicinal usage and livestock forage (IHPC, 2002; Bahmani et al., 2014). High levels of necessary nutritive minerals such as potassium, calcium, magnesium, sulfur, zinc and sodium, as well as phenols and vitamins particularly $A$ and $C$ are accessible in chicory (Jurgonski et al., 2011; Carazzone et al., 2013). Vegetable and forage production can be affected by many environmental factors so that in recent years drought stress extension is an important challenge for this crops production, drought stress lead to serious damage in plants root growth, water and nutrient uptake decreases and causes to yield reduce and also oxidative stress incitement with drought stress (Rahimian Boogar et al., 2014; Mârza et al., 2015; Zhao et al., 2015; Daryanto et al., 2016).
Plants accessibility to mineral nutrients particularly $\mathrm{K}, \mathrm{P}$ and $\mathrm{Ca}$ are necessary for tolerance to drought (Feng et al., 2015; Zhao et al., 2015). In addition, plants absorbancy of nutritional elements are depend to various factors such as the element natures, soil conditions (as: soil texture; clay and organic matter content, $\mathrm{pH}$ ) and soil amendment quality (Ben Achiba et al., 2009). Exogenous organic matter has different effects on instigation the mineral elements diffusion in the soil and their availability for plants (Zhang et al., 2015; Vanden Nest et al., 2016; Salehi et al., 2016). The cattle manure application lead to increases of potassium availability (as a necessary element in drought tolerance) and plant nourishment in the soil in compare with mineral fertilizers (Pires et al., 2008). Furthermore, application of organic manures and compost increase the soil organic carbon and $\mathrm{P}-\mathrm{CaCl}_{2}$, and $P$ leaching in compare with mineral fertilized soils (Vanden Nest et al., 2014), fulvic and humic synthesis (Vanden Nest et al., 2016) and epitomize the high content of organic materials in plants sowing bed (Ukale 
et al., 2016). In addition to macro-aggregates stability, the manure application increase the soil porosity and better infiltration of water, so increase water-holding capability and soil water content, and water use efficiency (Rasool et al., 2008; Karami et al., 2012; Liu et al., 2013; Ibrahim et al., 2015).

Application of organic manures is useful to produce the high nutritive value product. Regarding the negative effects of drought on plants nutritional quality, application of organic manure can be alleviate destructive effects of drought on chicory. The objective of this research was kept the suitable nutritional content and edible value of chicory, as well as support the physiology of growth under drought stress for improve the pharmaceutical indices.

\section{MATERIALS AND METHODS}

\section{Plants and experiment condition}

This research was carried out at the research farm of agricultural faculty in Zabol University, Sistan \& Balochestan, Iran. The weather of Zabol is hot and dry and summer is windy. Average of annual rainfall is 63 millimeters. Chicory seeds (type) were cultivated in March and plantlets were exposed to drought stress 30 days after planting.

\section{Manure treatments}

Manure treatments were applied in soil before seed sowing, applications of poultry and livestock manure added at rate of $30 \mathrm{t}$ $\mathrm{ha}^{-1}$ to soil with control treatment. Soil analysis was performed before planting (Table 1).

\section{Water stress treatment}

Water stress was applied from mid-May until the mid of July by limiting irrigation. Drought stresses were determined by application of evaporation pan (class-A). Three levels of water evaporation at surface of evaporate pan (Class A) was detected for irrigation intervals; $60 \mathrm{~mm}$ evaporation or well-watered (WW), $90 \mathrm{~mm}$ evaporation or moderate drought stress (MD) and $120 \mathrm{~mm}$ evaporation or severe drought stress (SD).

\section{Mineral nutrient assay and analysis}

Plant samples were harvested in mid-July for analyze. Samples were washed with distilled water and dried in oven at $70^{\circ} \mathrm{C}$ for $48 \mathrm{~h}$. The oven-dried subsamples were grounded, then nitrogen $(N)$ concentration was assayed with Kjeldahl method (Domini et al., 2009), and A Perkin Elmer Analyst 700 atomic absorption spectrometer with deuterium background corrector was applied for nutrient measurement in this experiment. Samples were ashed according to the standard method that prepared by ASTM C114-09 (ASTM, 2009). Ashed samples were dissolved in $0.1 \mathrm{~N} \mathrm{HCl}$ and then content increases to $100 \mathrm{ml}$. This extract was used for the quantification of $\mathrm{Mn}, \mathrm{Fe}$ and $\mathrm{Zn}$. Concentrations of $\mathrm{P}$ and $\mathrm{K}$ were detected with Spectrophotometer (BTS-45) according to the Motomizu et al. (1988) method and Flame Photometer (corning 400) according to the method described by ASTM (2009), respectively.

Analytical reagents; $\mathrm{HNO}_{3}, \mathrm{H}_{2} \mathrm{SO}_{4}, \mathrm{H}_{2} \mathrm{O}_{2}, \mathrm{HF}, \mathrm{HClO}_{4}$ and $\mathrm{HCl}(\mathrm{E}$. Merck) were used. The standard solutions of elements were created by extenuating a stock solution of $1000 \mathrm{mg} \mathrm{L}^{-1}(\mathrm{Mn})$ supplied by Sigma and (Zn, Fe) by Aldrich. Therefore, a standard stock solution for potassium $\left(1000 \mathrm{mg} \mathrm{L}^{-1}\right)$ was created by dissolving $0.1907 \mathrm{~g}$ of potassium chloride (Merck) in $0.1 \mathrm{M}$ hydrochloric acid and make adjustments as the final volume of $100 \mathrm{ml}$, and standard solution of phosphorus $\left(100 \mathrm{mg} \mathrm{L}^{-1}\right)$ was prepared by dissolving $0.2197 \mathrm{~g}$ of potassium dihydrogen phosphate $\left(\mathrm{KH}_{2} \mathrm{PO}_{4}\right)$ in water $(100 \mathrm{ml})$, therefore add $8 \mathrm{ml}$ Sulphuric acid $\left(\mathrm{H}_{2} \mathrm{SO}_{4}\right)$ and then dilute it into $500 \mathrm{ml}$. Double deionized water was used to prepare all stoke solutions for calibration.

\section{Extraction the total phenol and chicoric acid}

Total phenol was extracted according to the method of Ferioli and D'Antuono (2012) and Vitali et al. (2009) with some modification. Both leave and stem of chicory were harvested as described in the above experimental material and used liquid nitrogen tank for transport samples to lab. One gram of freeze-dried samples was crushed and homogenized by $15 \mathrm{ml}$ of methanol: $\mathrm{HCl}$ conc: water $(86: 2: 10 \mathrm{v} / \mathrm{v} / \mathrm{v})$ in a centrifuge tube and was shaken with a vortex for one minute, and ultrasonic bath was used for 15 minutes at room temperature and then centrifuged at $665 \times \mathrm{g}$ for $10 \mathrm{~min}$ at $5^{\circ} \mathrm{C}$

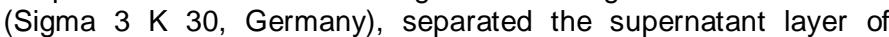
extract as extractable phenolic extraction. Finally, total phenol was measured with Folin-Ciocalteu colorimetric method (Apak et al., 2008), results were presented as milligrams of gallic acid equivalent (GAE) per 100 gram of fresh weight according to the method of Cefola et al. (2016), and calibration curve of gallic acid was plotted with eight points, from 25 to $500 \mathrm{mg} / \mathrm{L}$ with $\mathrm{R}^{2}=0.99$.

\section{Extraction of total carbohydrate and inulin}

Ten gram of fresh root was homogenized in $30 \mathrm{ml}$ of ice-cold $50 \mathrm{mM}$ sodium acetate buffer ( $\mathrm{pH} 5)$ with a blender for $1 \mathrm{~min}$. According to the modified method of van Arkel et al. (2012), then this mixture was used for carbohydrate and inulin analysis Timmermans et al. (1994) and Van den Ende et al. (1996).

\section{Statistical analysis}

Experiments were conducted in a randomized complete block design with three replications. Data were analyzed by factorial ANOVA at a significance level of $P \leq 0.05$ using SPSS v.22, and means were compared using LSD test.

Table 1. Physical and chemical properties of the soil at $0-30 \mathrm{~cm}$ depth.

\begin{tabular}{|c|c|c|c|c|c|c|c|c|c|c|c|c|}
\hline \multirow{2}{*}{ Soil texture } & Loam & Clay & Sand & $\mathrm{Fe}$ & Mn & $\mathrm{Zn}$ & $\mathbf{P}$ & $\mathrm{K}$ & $\mathbf{N}$ & \multirow{2}{*}{$\begin{array}{l}\text { Organic matter } \\
\text { (\%) }\end{array}$} & \multirow{2}{*}{ pH } & \multirow{2}{*}{$\begin{array}{l}\text { Electrical conductivity } \\
\text { (ds.m) }\end{array}$} \\
\hline & & (\%) & & \multicolumn{6}{|c|}{ (ppm) } & & & \\
\hline Sandy clay & 27.04 & 31.1 & 86.41 & 3.8 & 3.2 & 2.8 & 18 & 194 & 0.06 & 0.59 & 8.2 & 2.5 \\
\hline
\end{tabular}




\section{RESULTS}

\section{Mineral content}

Nutritious content of chicory was affected by water stress and soil fertility. So, two organic manure applications improve the nutritious value of chicory in water stress condition in compare with control condition, but poultry manure had the highest significant effects (Table 2).

\section{Nitrogen}

Nitrogen content was affected by water stress levels $\left(F_{2}\right.$, $27=81.27, P<0.01)$, and organic manure treatments $\left(\mathrm{F}_{2}\right.$, $27=3018.66, \mathrm{P}<0.01)$ in herbal part of chicory, this effect was not similar in all water stresses or manure treatments and peaked at poultry manure in three irrigation condition (Table 2). The magnitude of nitrogen differed between water stress and fertilizer treatments $\left(F_{4,27}=19.28, P<0.01\right)$. The poultry manure treatment resulted in the greatest increase in nitrogen content in chicory (Table 2).

\section{Potassium}

Potassium content significantly increased in chicory plant under water stress $\left(\mathrm{F}_{2}, 27=25.63, \mathrm{P}<0.01\right)$ and organic manure treatment $\left(F_{2}, 27=62.54, P<0.01\right)$, although this increase was not same for all treatments of water stress and fertilizer statistically the highest pointed in poultry and livestock manure at SD, and poultry manure at MD (Table 2). The degree of this increase in potassium content was not different between drought stress and organic manure $\left(F_{4,27}=1.42\right)$.

\section{Phosphorus}

Drought stress lead to significant decrease in phosphorus content of chicory plant $\left(F_{2}, 27=32.09 \mathrm{P}<0.01\right)$, so application of all organic fertilizer treatments $\left(\mathrm{F}_{2}, 27=\right.$ $69.36 \mathrm{P}<0.01)$ had significant effect on improving the phosphorus content in chicory. The lowest content of phosphorus is existing in SD condition. However, poultry organic fertilizer has the highest significant effect on phosphorus accumulation in all condition (Table 2). However, the rate of phosphorus decreases is similar between drought stress and organic fertilizer treatments $\left(F_{2}, 27=0.86\right)$, interaction of drought stress with organic fertilizers is not significant.

\section{Zinc}

All treatments of drought stress and organic fertilizer were effected on zinc content of chicory, according to this result water stress $\left(F_{2,27}=269.57 \mathrm{P}<0.01\right)$, and organic fertilizer $\left(F_{2}, 27=104.57, P<0.01\right)$ increased zinc content significantly. Though this effect was not same for all treatments of water stresses and organic fertilizer, and peaked at SD with organic livestock manure (Table 2). The interaction of water stress and manure treatments $\left(F_{4,27}=11.71, P<0.01\right)$ has a significant effect on process of zinc increasing (Table 2).

\section{Iron}

Iron content in chicory plant was affected by all treatments of drought stress $\left(F_{2,27}=268.20 P<0.01\right)$, and organic manure treatments $\left(F_{2}, 27=310.26, P<\right.$ 0.01). Significantly, this effect was not like in all treatments and highest content obtained at poultry manure at WW (Table 2). However, drought and organic manure interactions $\left(F_{4}, 27=1.86\right)$ was not significant (Table 2).

\section{Manganese}

Manganese content was reduced significantly in chicory plant under drought stress $\left(\mathrm{F}_{2,27}=43.04, \mathrm{P}<0.01\right)$ and improved by organic manure treatment $\left(F_{2}, 27=192.69, P\right.$ $<0.01)$. Although the effects of all treatments of water stress and fertilizer is not same and the poultry organic fertilizer has the highest effect on manganese content increases under WW and MD condition (Table 2). Interaction between drought stresses with organic fertilizer $\left(F_{4,27}=3.99, P<0.05\right)$ is significant.

\section{Biochemical content}

\section{Total phenol}

The chicory total phenol significantly increased by drought stress $\left(F_{2}, 27=46.90, P<0.01\right)$ and organic manure treatment $\left(F_{2,27}=28.51, P<0.01\right)$, also effect of drought stress and organic fertilizer treatments on increases of phenolic compound was not alike and highest content of phenol pointed in both of organic manure at SD (Table 3). The magnitude of phenolic increases was not depending to interaction of drought stress with organic manure $\left(\mathrm{F}_{4,27}=2.74\right)$.

\section{Chicoric acid}

Chicoric acid were significantly affected by drought stress $\left(F_{2}, 27=181.52, P<0.01\right)$ and organic manure treatment $\left(F_{2}, 27=63.06, P<0.01\right)$, however effects of different treatments of drought and fertilizer was not same on 
Table 2. The effects of organic manures treatments on chicory mineral content under drought stress.

\begin{tabular}{|c|c|c|c|c|c|c|c|}
\hline Drought stress & Organic fertilizer & $\mathbf{N}(\%)$ & $\mathbf{P}(\%)$ & $\mathrm{K}(\%)$ & $\mathrm{Fe}$ (ppm) & Zn (ppm) & Mn (ppm) \\
\hline \multirow{3}{*}{ Well-Watered (WW) } & Poultry & $2.21^{\text {a† }}$ & $1.13^{\mathrm{a}}$ & $0.96^{\mathrm{cd}}$ & $145.53^{\mathrm{a}}$ & $48.44^{\mathrm{e}}$ & $41.19^{a}$ \\
\hline & Livestock & $0.70^{d}$ & $0.92^{b}$ & $0.93^{\mathrm{cd}}$ & $132.05^{\mathrm{C}}$ & $53.11^{d}$ & $30.90^{\mathrm{b}}$ \\
\hline & control & $0.55^{\dagger}$ & $0.81^{\mathrm{cd}}$ & $0.53^{f}$ & $126.46^{\mathrm{d}}$ & $42.25^{\dagger}$ & $18.07^{d}$ \\
\hline \multirow{3}{*}{ Moderate Drought (MD) } & Poultry & $1.91^{\mathrm{b}}$ & $1.06^{\mathrm{a}}$ & $1.30^{\mathrm{ab}}$ & $135.69^{b}$ & $56.76^{\mathrm{c}}$ & $40.09^{\mathrm{a}}$ \\
\hline & Livestock & $0.63^{\mathrm{de}}$ & $0.86^{b c}$ & $1.13^{b c}$ & $125.97^{d}$ & $58.94^{\mathrm{bc}}$ & $25.92^{\mathrm{C}}$ \\
\hline & control & $0.47^{g}$ & $0.70^{\text {ef }}$ & $0.66^{\mathrm{ef}}$ & $116.90^{\mathrm{e}}$ & $51.17^{\mathrm{de}}$ & $13.23^{\mathrm{e}}$ \\
\hline \multirow{3}{*}{ Severe Drought (SD) } & Poultry & $1.70^{\mathrm{C}}$ & $0.88^{\mathrm{bc}}$ & $1.50^{\mathrm{a}}$ & $126.43^{\mathrm{d}}$ & $60.23^{b}$ & $27.91^{\mathrm{bc}}$ \\
\hline & Livestock & $0.60^{\mathrm{ef}}$ & $0.73^{\mathrm{de}}$ & $1.40^{\mathrm{a}}$ & $116.86^{\mathrm{e}}$ & $73.81^{\mathrm{a}}$ & $19.74^{d}$ \\
\hline & control & $0.37^{\mathrm{h}}$ & $0.63^{\dagger}$ & $0.76^{\text {de }}$ & $109.42^{\dagger}$ & $60.96^{\mathrm{b}}$ & $11.65^{\mathrm{e}}$ \\
\hline \multicolumn{8}{|l|}{ Significance } \\
\hline Drought stress (DS) & & $* * *$ & $\star * * *$ & *** & $\star \star \star *$ & *** & 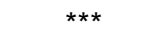 \\
\hline Organic fertilizer (OF) & & $\star \star \star *$ & $\star \star \star *$ & *** & *** & *** & *** \\
\hline $\mathrm{DS} \times \mathrm{OF}$ & & $* * *$ & ns & $\mathrm{ns}$ & ns & $* * *$ & * \\
\hline
\end{tabular}

${ }^{\dagger}$ Different letters in each column indicate significant difference between means.

${ }^{* * *}$ significant at 0.001 ; *significant at 0.05 ; ns not significant.

Table 3. Effects of organic manures treatments on chicory biochemical content under drought stress.

\begin{tabular}{|c|c|c|c|c|c|}
\hline Drought stress & $\begin{array}{l}\text { Organic } \\
\text { fertilizer }\end{array}$ & 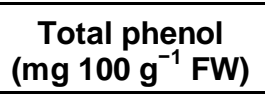 & 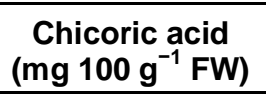 & $\begin{array}{c}\text { Total carbohydrate } \\
\left(\mathrm{mg} \mathrm{g}^{-1} \mathrm{FW}\right)\end{array}$ & $\begin{array}{c}\text { Inulin } \\
\text { ( } \mathrm{mg} \mathrm{g}^{-1} \mathrm{DW} \text { of root) }\end{array}$ \\
\hline \multirow{3}{*}{ Well-Watered (WW) } & Poultry & $196^{\mathrm{bc} \dagger}$ & $36.76^{\mathrm{e}}$ & $6.82^{f}$ & $73.36^{\mathrm{a}}$ \\
\hline & Livestock & $184^{\mathrm{C}}$ & $43.46^{d}$ & $6.48^{\dagger}$ & $74.64^{\mathrm{a}}$ \\
\hline & Control & $165^{d}$ & $35.44^{\mathrm{e}}$ & $6.37^{\dagger}$ & $70.00^{b}$ \\
\hline \multirow{3}{*}{ Moderate Drought (MD) } & Poultry & $201^{\mathrm{b}}$ & $63.34^{\mathrm{b}}$ & $8.69^{d}$ & $64.23^{d}$ \\
\hline & Livestock & $193^{\mathrm{bc}}$ & $76.96^{\mathrm{a}}$ & $8.45^{\text {de }}$ & $65.48^{\mathrm{cd}}$ \\
\hline & Control & $187^{\mathrm{bc}}$ & $53.71^{\mathrm{c}}$ & $7.85^{\mathrm{e}}$ & $52.89^{f}$ \\
\hline \multirow{3}{*}{ Severe Drought (SD) } & Poultry & $237^{\mathrm{a}}$ & $55.62^{c}$ & $14.25^{\mathrm{a}}$ & $67.55^{\mathrm{bc}}$ \\
\hline & Livestock & $225^{\mathrm{a}}$ & $57.49^{c}$ & $12.74^{\mathrm{b}}$ & $69.17^{b}$ \\
\hline & Control & $194^{\text {bc }}$ & $42.06^{d}$ & $10.53^{\mathrm{c}}$ & $58.26^{\mathrm{e}}$ \\
\hline \multicolumn{6}{|l|}{ Significance } \\
\hline Drought stress (DS) & & 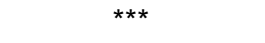 & 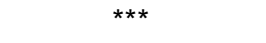 & *** & *** \\
\hline Organic fertilizer (OF) & & *** & 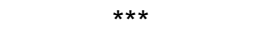 & 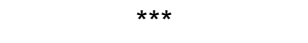 & *** \\
\hline $\mathrm{DS} \times \mathrm{OF}$ & & ns & 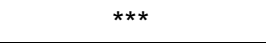 & 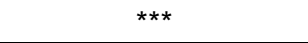 & 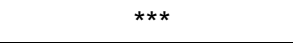 \\
\hline
\end{tabular}

${ }^{\dagger}$ Different letters in each column indicate significant difference between means.

${ }^{* * \star}$ Significant at 0.001 ; *significant at 0.05 ; ns not significant.

chicoric acid increases and highest content of chicoric acid obtained in livestock manure at MD (Table 3). The greatness of chicoric acid increases was depending on interaction of drought stress with organic manure $\left(\mathrm{F}_{4,27}=\right.$ 7.38, $\mathrm{P}<0.01)$. HPLC analyzes of chicory extract carried out for determination the chicoric acid in different treatment (Figure 1).

\section{Total carbohydrate}

Total carbohydrate content was affected by drought stress $\left(F_{2}, 27=586.84, P<0.01\right)$, organic manure $\left(F_{2,27}=\right.$ 44.32, $\mathrm{P}<0.01)$ and interaction of drought stress with organic manure $\left(F_{4}, 27=17.16, P<0.01\right)$, significantly. Therefore, the effects of drought stress and organic 

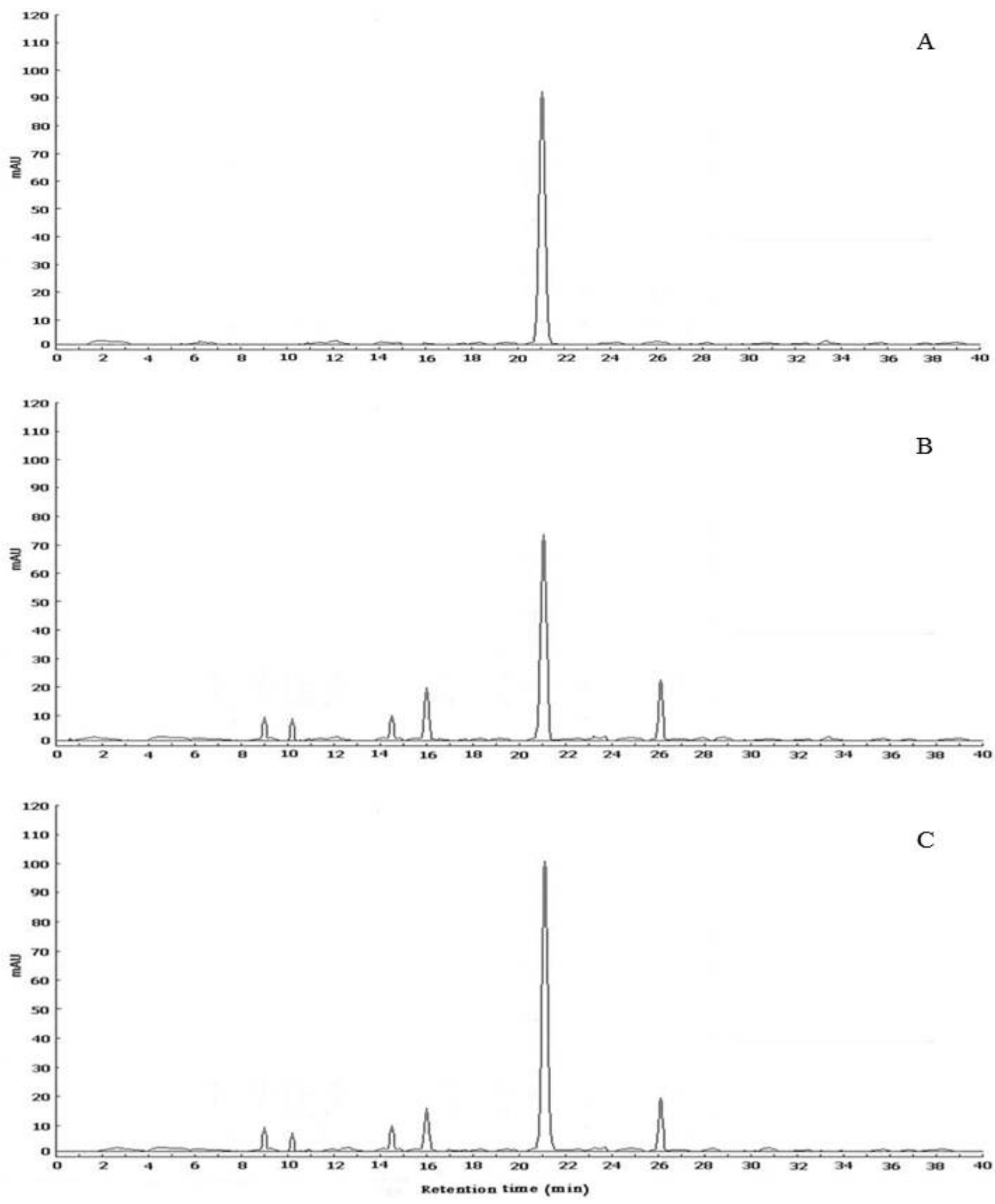

Figure 1. HPLC chromatogram for chicoric acid. A; standard of chicoric acid (40 micrograms per ml). B; peak of chicoric acid at poultry manure treatment. C; peak of chicoric acid at livestock manure treatment.

manure were not the same for all treatments (Table 3). According to these results, the highest carbohydrate content accumulated at the SD condition than MD and WW condition, as well as the poultry manure have higher effect on carbohydrate increases under drought than livestock treatment though both organic manure have had the significant effects than control.

\section{Inulin}

The root inulin concentrations were significantly affected 
by drought stress $\left(F_{2,27}=155.18, P<0.01\right)$ and organic fertilizer $\left(F_{2}, 27=111.02, P<0.01\right)$, so this effect is not same for drought and organic fertilizers in all treatment (Table 3). As well as, interaction of the two factors $\left(F_{4}, 27\right.$ $=8.35, \mathrm{P}<0.01)$ have a significant effect on root inulin content.

\section{DISCUSSION}

This research showed a positive effect of organic manure on the mineral nutrient and chemical compound of chicory grown in drought stress condition. The positive responsiveness of chicory to application of poultry and livestock manure under drought stress confirms the crucial role of manure usage for growth supplementation in the low water environments. In the present study, we observed that applications of different manure for alleviating the effects of drought stress on chicory were showed the significant effect of both manure and their interaction with drought on nutrient content, chicoric acid and root inulin. In WW condition the accumulation of N, $\mathrm{P}, \mathrm{Fe}$ and $\mathrm{Mn}$ concentration was higher in above ground part of chicory than other measured nutritious when poultry manure used. Although both of organic manure treatments had the significant effects on accumulation of mineral nutrient in chicory than control treatment, this results in accordance with the effects of manure fertilization on increases the $\mathrm{N}$ and $\mathrm{P}$ in above ground part of various plants (Demir et al., 2010; Vieira Pacheco et al., 2017; Herencia et al., 2011). Therefore, under WW condition both organic manure have low effect on $\mathrm{K}$ and $\mathrm{Zn}$ accumulation in chicory plants which is related to water availability and the effect of water on nutrient releases in soil and nutrient absorption by plants, but not related to the amount of nutrient in organic manure. This result is alike with the effect of cattle manure on $\mathrm{K}$ accumulation in yellow passion fruit (Vieira Pacheco et al., 2017), and Zn content in leaves of chicory (Haag and Minami, 1998).

In the MD condition, the $\mathrm{P}, \mathrm{K}$ and $\mathrm{Mn}$ had the highest concentration in above ground part of chicory than other measured nutritious, as well as poultry manure had higher effect on the accumulation of $\mathrm{P}, \mathrm{K}$ and $\mathrm{Mn}$ in compare with livestock manure. Though, the effect of both usage manure was significant than control treatment. Howbeit, in the SD condition the $\mathrm{K}$ and $\mathrm{Zn}$ had a higher concentration than other mineral nutrient and livestock manure had the highest effect on the $\mathrm{K}$ and $\mathrm{Zn}$ accumulation under SD condition. The high concentration of $\mathrm{K}$ in plants which were grown under drought stress is alignment with the role of $\mathrm{K}$ as a mechanism for contribute to osmotic adjustment (Nio et al., 2011; Feng et al., 2015). In this regard, Zhao et al. (2010) reported high concentration of $\mathrm{K}$ in high-drought-tolerant genotypes of barley under drought stress. Furthermore, organic fertilizers have positive effects on increases the cation exchange capacity in soil and lead to increase the level of available K (Herencia et al., 2011). Moreover, Demir et al. (2010) were shown the significant effects of poultry manure on concentrations of $\mathrm{Zn}$ in tomato leaf, that accordance with previous study application of two organic manure causes to $\mathrm{Zn}$ accumulation in chicory leaf. Moreover, application of several organic manures increases the Zn content in soil (Uprety et al., 2009).

Some biochemical characteristic of chicory includes; total phenolic compound, chicoric acid, total carbohydrate and inulin were affected by drought stress, in accordance with this result previous studies were shown the total phenol increased under drought stress (Oh et al., 2010; Gharibi et al., 2016). Furthermore, both organic manures were applied under WW, MD and SD condition improved phenolic compound and other biochemical characteristic, so that the highest concentration of total phenol was obtained under SD condition with both manure applications. Previous studies in accordance with our result were reported the total phenol increases in organic farming (Oliveira et al., 2013; Vinha et al., 2014), and recently Sunday (2016) showed that the significant effects of poultry manure on phenols increases as phytochemical compound in the Roselle. Chicoric acid was determined as a main phenolic compound in chicory, it has shown significant difference in all treatment and this effect was related to drought stress and organic manure treatments. And the highest accumulation of chicoric acid was obtained at MD condition with livestock treatment. Formerly, Galieni et al. (2015) were reported drought stress improved the accumulation of chicoric acids in the bound forms.

Carbohydrates content in vegetative parts of different plants were recognized as a mechanism for response to drought stress (Iglesias et al., 2002; Pedroso et al., 2014; Nyarukowa et al., 2016). According to this study, carbohydrate scrutiny showed a higher concentration of carbohydrate obtained in herbal parts of chicory at SD condition and poultry manure treatment than other treatments which this result is accordance with effects of drought on carbohydrate concentrations in drought sensitive plant cultivars (Iordachescu and Imai, 2008; Nyarukowa et al., 2016). In addition, Xie et al. (2014) showed that manure amendments significantly increase neutral sugar concentrations in bulk soil in free and occluded particulate organic matter and the neutral sugars can be attributed to plant. Also, other previous studies have shown the high content of carbohydrate compound in dairy manure and poultry litter (Meyer et al., 2002; Wang et al., 2011; He and Olk, 2011). Moreover, drought can influence the inulin metabolism as a main reserve carbohydrate in chicory (De Roover et al., 2000), in addition the inulin accumulation in chicory showed a time followed sigmoid curve and some stresses such as drought and nutritional stress perhaps can still be important factors in inulin degradation (van Arkel et al., 2012). In accordance to previous studies, present 
research showed which inulin content in chicory root was significantly affected by both treatments of drought and organic manure, and the highest concentration of inulin obtained in WW and both poultry and livestock manures.

\section{Conclusion}

Nutritional quality of edible herbs is important for consumers' health especially in plants that grow in arid and semi-arid areas. Water deficit is a major limiting factor in plant ability to uptake nutrition and causes poor nutritional production. Application of organic manures improved stoke of nutritious substrate and accessible water in the soil, through with this mechanism organic manure can increase in nutritious qualitative index and scale of chicory biomass production. Due to world warming and land aridity, different organic manure sources suggest to investigate for alleviate negative effects of water deficit on edible plants which produce in water stress condition.

\section{ACKNOWLEDGMENTS}

The authors acknowledge the valuable assistance of the Department of Horticulture science staff, Zabol University.

\section{REFERENCES}

Apak R, Güçlü K, Özyürek M, Çelik SE, 2008. Mechanism of antioxidant capacity assays and the CUPRAC (cupric ion reducing antioxidant capacity) assay. Microchimica Acta, 160(4): 413-419.

ASTM, 2009. International standard, "Standard test methods for chemical analysis of hydraulic cement (ASTM C114-09)" West Conshohocken, $\mathrm{Pa}$, USA.

Bahmani M, Zargaran A, Rafieian-Kopaei M, 2014. Identification of medicinal plants of Urmia for treatment of gastrointestinal disorders. Rev Bras Farmacogn, 24: 468-480.

Ben Achiba W, Gabteni N, Lakhdar A, Du Laing G, Verloo M, Jedidi N, Gallali T, 2009. Effects of 5-year application of municipal solid waste compost on the distribution and mobility of heavy metals in a Tunisian calcareous soil. Agric Ecosyst Environ, 130(3-4): 156-163.

Carazzone C, Mascherpa D, Gazzani G, Papetti A, 2013. Identification of phenolic constituents in red chicory salads (Cichorium intybus) by high performance liquid chromatography with diode array detection and electrospray ionisation tandem mass spectrometry. Food Chem, 138(2-3): 1062-1071.

Castellini C, Cardinali R, Rebollar PG, Dal Bosco A, Jimeno V, Cossu $\mathrm{ME}, 2007$. Feeding fresh chicory (Chicoria intybus) to young rabbits: Performance, development of gastro-intestinal tract and immune functions of appendix and Peyer's patch. Anim Feed Sci Technol, 134: 56-65.

Cefola M, Carbone V, Minasi P, Pace B, 2016. Phenolic profiles and postharvest quality changes of fresh-cut radicchio (Cichorium intybus L.): nutrient value in fresh vs. stored leaves. J Food Composit Anal, 51: $76-84$

Daryanto S, Wang L, Jacinthe P, 2016. Global synthesis of drought effects on cereal, legume, tuber and root crops production: A review. Agric Water Manag, 179: 18-33.

De Roover J, Vandenbranden K, Van Laere A, Van den Ende W, 2000. Drought induces fructan synthesis and 1-SST (sucrose:sucrose fructosyltransferase) in roots and leaves of chicory seedlings (Cichorium intybus L.). Planta, 210: 808-814.

Demir K, Sahin O, Kadiogluc YK, Pilbeam DJ, Gunes A, 2010. Essential and non-essential element composition of tomato plants fertilized with poultry manure. Scientia Horticulturae, 127: 16-22.

Domini C, Vidal L, Cravotto G, Canals A, 2009. A simultaneous, direct microwave/ultrasound-assisted digestion procedure for the determination of total Kjeldahl nitrogen. Ultrasonics Sonochem, 16: 564-569.

Feng X, Liu W, Zeng F, Chen Z, Zhang G, Wu F, 2015. $\mathrm{K}^{+}$Uptake, $\mathrm{H}^{+}$ATPase pumping activity and $\mathrm{Ca}^{2+}$ efflux mechanism are involved in drought tolerance of barley. Environ Exper Bot, 129: 57-66.

Ferioli F, D'Antuono LF, 2012. An update procedure for an effective and simultaneous extraction of sesquiterpene lactones and phenolics from chicory. Food Chem, 135: 243-250.

Galieni A, Di Mattia C, De Gregorio M, Speca S, Mastrocola D, Pisante $M$, Stagnari F, 2015. Effects of nutrient deficiency and abiotic environmental stresses onyield, phenolic compounds and antiradical activity in lettuce (Lactuca sativa L.). Scientia Horticulturae, 187: 93101.

Gharibi S, Tabatabaei BE, Saejdi G, Goli SA, 2016. Effect of drought stress on total phenolic, lipid peroxidation, and antioxidant activity of Achillea species. Appl Biochem Biotechnol, 178(4): 796-809.

Haag HP, Mianami K, 1998. Mineral nutrition of vegetable crops. Absorption of nutrients by chicory crop. Anaisda-Escola-SuperiordeAgricultura. Luiz-de-Queiroz, 45(2): 257-603.

He Z, Olk DC, 2011. Manure amino compounds and their bioavailability. In: He Z (ed.) Environmental Chemistry of Animal Manure. Nova Science Publishers, New York. pp.179-199.

Herencia JF, Garcá-Galavís PA, Dorado JAR, Maqueda C, 2011. Comparison of nutricional quality of the crops grown in an organic and conventional fertilized soil. Scientia Horticulturae, 129(4): 882888.

Ibrahim A, Abaidoo RC, Fatondji D, Opoku A, 2015. Hill placement of manure and fertilizer micro-dosing improves yield and water use efficiency in the Sahelian low input millet-based cropping system. Field Crops Res, 180: 29-36.

Iglesias DJ, Lliso I, Tadeo FR, Talon M, 2002. Regulation of photosynthesis through source: sink imbalance in citrus is mediated by carbohydrate content in leaves. Physiologia Plantarum, 116(4): 563-572.

IHPC (Iranian Herbal Pharmacopoeia Committee), 2002. Iranian Herbal Pharmacopoeia. Iranian Ministry of Health Publishers. Tehran. pp: 578-588.

Iordachescu M, Imai R, 2008. Trehalose biosynthesis in response to abioticstresses. J Integrative Plant Biol, 50(10): 1223-1229.

Jurgonski A, Milala J, Juskiewicz J, Zdunczyk Z, Krol B, 2011. Composition of chicory root, peel, seed and leaf ethanol extracts and biological properties of their non-inulin fractions. Food Technol Biotechnol, 49(1): 40-47.

Karami A, Homaee M, Afzalinia S, Ruhipour H, Basirat S, 2012. Organic resource management: impacts on soil aggregate stability and other soil physicochemical properties. Agric Ecosyst Environ, 148: 22-28.

Liu CA, Li FR, Zhou LM, Zhang RH, Jia Y, Lin SL, Wang LJ, Siddique KHM, Li FM, 2013. Effect of organic manure and fertilizer on soil water and crop yields in newly-built terraces with loess soils in a semi-arid environment. Agric Water Manag, 117: 123-132.

Mârza B, Angelescu C, Tindeche C, 2015. Agricultural Insurances and Food Security. The New Climate Change Challenges. Proc Econ Finan, 27: 594-599.

Meyer RL, Kjaer T, Revsbech NP, 2002. Nitrification and denitrification near a soil-manure interface studied with a nitrate-nitrite biosensor. Soil Sci Soc Am J, 66: 498-506.

Motomizu S, Oshima M, Hirashima A, 1988. Spectrophotometric determination of phosphorus in river water based on the reaction of vanadomolybdophosphate with malachite green. Analytica Chimica Acta, 211: 119-127.

Mulabagal V, Wang H, Ngouajio M, Nair MG, 2009. Characterization and quantification of health beneficial anthocyanins in leaf chicory (Cichorium intybus) varieties. European Food Res Technol, 230: 4753. 
Nio SA, Cawthray GR, Wade LJ, Colmer TD, 2011. Pattern of solutes accumulated during leaf osmotic adjustment as related to duration of water déficit for wheat at the reproductive stage. Plant Physiol Biochem, 49(10): 1126-1137.

Nyarukowa C, Koech R, Loots T, Apostolides Z, 2016. SWAPDT: A method for short-time withering assessment of probability for drought tolerance in Camellia sinensis validated by targeted metabolomics. J Plant Physiol, 198: 39-48.

Oh MM, Carey EE, Rajashekar CB, 2010. Regulated water deficits improve phytochemical concentration in lettuce. J Am Soc Horticultural Sc, 135: 223-229.

Oliveira AB, Moura CFH, Gomes-Filho E, Marco CA, Urban L, Miranda MRA, 2013. The impact of organic farming on quality of tomatoes is associated to increased oxidative stress during fruit development. PLoS ONE, 8(2): e56354.

Pedroso FKJV, Prudente DA, Bueno ACR, Machado EC, Ribeiro RV, 2014. Drought tolerance in citrus trees is enhanced by rootstockdependent changes in root growth and carbohydrate availability. Environ Exper Bot, 101: 26-35.

Pires AA, Monnerat PH, Marciano CR, Pinho LGR, Zampirolli PD, Rosa RCC, Muniz RA, 2008. Alternative manuring of the yellow passion fruit plant: Effects on chemical and physical characteristics of the soil. Revista Brasileira de Ciência do Solo, 32(5): 1997-2005.

Rahimian Boogar A, Salehi H, Jowkar A, 2014. Exogenous nitric oxide alleviates oxidative damage in turf grasses under drought stress. South Afr J Bot, 92: 78-82.

Rasool R, Kukal SS, Hira GS, 2008. Soil organic carbon and physical properties as affected by long-term application of FYM and inorganic fertilizers in maize-wheat system. Soil Till Res, 101(1-2): 31-36.

Salehi A, Tasdighi H, Gholamhoseini M, 2016. Evaluation of proline, chlorophyll, soluble sugar content and uptake of nutrients in the German chamomile (Matricaria chamomilla L.) under drought stress and organic fertilizer treatments. Asian Pac J Trop Biomed, 6(10): 886-891.

Sinkovič L, Demsar L, Žnidarčič D, Vidrih R, Hribar J, Treutter D, 2015. Phenolic profiles in leaves of chicory cultivars (Cichorium intybus L.) as influenced by organic and mineral fertilizers. Food Chem, 166: 507-513.

Sunday A, 2016. Impact of organic and folia fertilizer application on the growth, yield and medicinal potential of Hybiscus sabdariffa L. Global J Agric Res, 4(2): 7-17.

Timmermans JW, van Leeuwen MB, Tournois $H$, de Wit $D$, Vliegenthart JFG, 1994. Quantitative analysis of the molecular weight distribution of inulin by means of anion exchange HPLC with pulsed amperometric detection. J. Carbohydrate Chem, 13(6): 881-888.

Ukale DU, Bhagwat RV, Upadhyay SK, Cukkemane N, Cukkemane AA, 2016. Metabolic analysis of liquid formulations of organic manures and its influence on growth and yield of Solanum lycopersicum L. (tomato) crop in field. Biocatalysis Agric Biotechnol, 8: 50-54.

Uprety D, Hejcman M, Száková J, Kunzová E, Tlustoŝ P, 2009. Concentration of trace elements in arable soil after long-term application of organic fertilizers. Nutrient Cycling in Agroecosyst, 85(3): 241-252.

van Arkel J, Vergauwen R, Sévenier R, Hakkert JC, van Laere A, Bouwmeester HJ, Koops AJ, van der Meer IM, 2012. Sink filling, inulin metabolizing enzymes and carbohydrate status in field grown chicory (Cichorium intybus L.). J Plant Physiol, 169: 1520-1529.

Van den Ende W, De Roover J, van Laere A, 1996. In vitro synthesis of fructofuranosyl-only oligosaccharides from inulin and fructose by purified chicory root fructan: fructan fructosyl transferase. Physiologia Plantarum, 97: 346-52.

Vanden Nest T, Ruysschaert G, Vandecasteele B, Houot S, Baken S, Smolders E, Cougnon M, Reheul D, Merckx R, 2016. The long term use of farmyard manure and compost: Effects on $P$ availability, orthophosphate sorption strength and $\mathrm{P}$ leaching. Agric Ecosyst Environ, 216: 23-33.

Vanden Nest T, Vandecasteele B, Ruysschaert G, Cougnon M, Merckx $R$, Reheul D, 2014. Effect of organic and mineral fertilizers on soil $P$ and $C$ levels, crop yield and potential $P$ leaching in a long term trial on a silt loam soil. Agric Ecosyst Environ, 197: 309-317.
Vieira Pacheco AL, Pagliarini MF, de Freitas GB, Silva Santos RH, Serrão JE, Zanuncio JC, 2017. Mineral composition of pulp and production of the yellow passion fruit with organic and conventional fertilizers. Food Chem, 21: 425-430.

Vinha AF, Barreira SVP, Costa ASG, Alves RC, Oliveira MBPP, 2014. Organic versus conventional tomatoes: influence on physicochemical parameters, bioactive compounds and sensorial attributes. Food Chem Toxicol, 67: 139-144.

Vitali D, Dragojevic IV, Sebecic B, 2009. Effects of incorporation of integral raw materials and dietary fibre on the selected nutritional and functional properties of biscuits. Food Chem, 114: 1462-1469.

Wang JJ, Dodla SK, He Z, 2011. Application of analytical pyrolysismass spectrometry in characterization of animal manure. In $\mathrm{He} \mathrm{Z}$ (ed.) Environmental Chemistry of Animal Manure. Nova Science Publishers, New York. pp. 3-24.

Xie H, Li J, Zhu P, Peng C, Wang J, He H, Zhang X, 2014. Long-term manure amendments enhance neutral sugar accumulation in bulk soil and particulate organic matter in a Mollisol. Soil Biol Biochem, 78: 4553.

Zhang X, Dong W, Dai X, Schaeffer S, Yang F, Radosevich M, Xu L, Liu X, Sun X, 2015. Responses of absolute and specific soil enzyme activities to long term additions of organic and mineral fertilizer. Sci Total Environ, 536: 59-67.

Zhao J, Sun H, Dai H, Zhang G, Wu F, 2010. Difference in response to drought stress among Tibet wild barley genotypes. Euphytica, 172: 395-403.

Zhao R, Guo W, Bi N, Guo J, Wang L, Zhao J, Zhang J, 2015. Arbuscular mycorrhizal fungi affect the growth, nutrient uptake and water status of maize (Zea mays L.) grown in two types of coal mine spoils under drought stress. Appl Soil Ecol, 88: 41-49.

Citation: Rahimian Boogar A, Saedi F, M osavi Nik SM, 2018. Effect of organic manures on nutritional quality of chicory under water deficit. Adv M ed Plant Res, 6(3): 46-53. 